\title{
The world has a unique opportunity: Accelerating technology transfer and vaccine production through partnerships
}

\author{
Xiaolan Fu' ${ }^{1}$, Peter J. Buckley², \\ Diego Sanchez-Ancochea ${ }^{3}$ \\ and Ines Hassan ${ }^{4}$

\footnotetext{
${ }^{1}$ Technology and Management Centre for Development, Department of International Development, University of Oxford, Oxford OX1 3TB, UK; ${ }^{2}$ Leeds University Business School, University of Leeds, Leeds LS2 9JT, UK;

${ }^{3}$ Department of International Development, University of Oxford, Oxford OX1 3TB, UK;

${ }^{4}$ International Science Council, Paris, France
}

\section{Correspondence:}

$\mathrm{X} \mathrm{Fu}$, Technology and Management Centre for Development, Department of International Development, University of Oxford, Oxford OX1 3TB, UK e-mail: xiaolan.fu@qeh.ox.ac.uk

\begin{abstract}
The global roll-out of vaccines is crucial to defeating the pandemic, but the lack of technical know-how and manufacturing infrastructure for production are constraining the speedy provision of vaccines globally. This will remain true even if the intellectual property rights of COVID-19 vaccines are waived temporarily. To accelerate technology transfer and global vaccine production, this article calls for the promotion of joint ventures between global COVID-19 vaccine manufacturers and local pharmaceutical companies so as to create regional manufacturing hubs. These joint ventures must be supported financially by global North countries, international organisations, and hostcountry governments. This approach will incentivize pharmaceutical companies to share not only their patents but also tacit production knowledge because the risk and cost of setting up new facilities will be shared. In this paper, we show how the joint venture approach will have benefits for all the actors involve and generate positive impact on Sub-Saharan Africa and other regions over the long run. Following these policy proposals will not only help protect the global community from COVID-19 but will also present a rare window of opportunity to stimulate the life science industry in the global South, supporting sustainable economic and technological development.
\end{abstract}

Journal of International Business Policy (2022) 5, 406-415.

https://doi.org/10.1057/s42214-021-00124-7

Keywords: COVID-19; technology transfer; partnerships; alliances; joint ventures

\section{THE CHALLENGE}

It is widely recognized that the global roll-out of vaccines is crucial to defeating the COVID-19 pandemic (Middleton et al., 2021). This includes rapidly closing the gap in the vaccination uptake between the "global North" and "global South" to minimise the likelihood of severe acute respiratory syndrome coronavirus 2 (SARS-CoV-2) variants causing current vaccines to be less effective in the future. In the UK and US, 71 and 61\%, respectively, of people had received at least one dose of the vaccine by August 2021, while only 1.3\% of total doses have so far gone to LICs (Our World in Data, 2021). Boosting vaccine production capacity globally has become a critical
Received: 14 July 2021

Revised: 5 October 2021

Accepted: 16 October 2021

Online publication date: 10 November 2021 
priority for the global community. In Africa, there are fewer than ten African manufacturers with vaccine production and there is very limited upstream production capacity with most local companies only engaging in packaging and labelling (WHO, 2021). Although the Coalition for Epidemic Preparedness Innovations (CEPI), the Global Alliance for Vaccines and Immunizations (Gavi), and the COVID-19 Vaccines Global Access Facility (COVAX, which is co-led by CEPI, Gavi and WHO) have provided seed funding and led matchmaking efforts to convince manufacturers to start scaling-up global production, a lack of capital investment, patented and tacit knowledge of vaccine production, a shortage of inputs, and the ongoing threat of 'vaccine nationalism' are impeding the much-needed expansion of global vaccine production (Athreye, 2021a; Bown, 2021; Meyer, 2021; Shadlen, 2020).

\section{ALTERNATIVE SOLUTIONS AND ITS LIMITATIONS}

In 2020, India and South Africa proposed that the World Trade Organisation (WTO) suspend IP rights related to the "prevention, containment and treatment" of COVID-19. In May 2021, the United States president announced his support for calls to temporarily waive intellectual property (IP) patents protections for COVID-19 vaccines (Office of the United States Trade Representative, 2021). The idea was to allow generic and biosimilar manufacturers to immediately produce more affordable versions of products such as vaccines, medicines and diagnostics without waiting years for key patents to expire.

While the temporary waiver of vaccine IP is important, it will be insufficient to accelerate the production of vaccines rapidly (Gonsalves, 2021; Hotez, Bottazzi, \& Yadav, 2021; Shadlen, 2020). When pharmaceutical companies failed to cut the extortionate prices of vital drugs for HIV/AIDs two decades ago, the Trade-Related Aspects of Intellectual Property (TRIPS) waiver was mostly used as a negotiation tool to decrease drug prices. However, with COVID-19 vaccines, supply is a bigger issue than affordability (Dyer, 2021). Vaccine manufacturing is a particularly complex process that, in the case of COVID-19, has demanded an advanced level of technical know-how and manufacturing infrastructure to innovate the COVID-19 vaccine. For instance, Pfizer states that the production of mRNA vaccines requires highly specialised raw materials: 280 components produced by suppliers in 19 countries. It also suggests that production infrastructure using mRNA technology had to be built from scratch because such facilities did not exist anywhere in the world. Nevertheless, scientists at Moderna have estimated that future mRNA facilities can be built in 3-4 months (Cheng \& Hinnant, 2021), without including the time required for site regulatory approval.

It is clear that to increase manufacturing capacity quickly and effectively, technical and knowledge transfer is necessary (WHO, 2021). Even if the WTO adopts the patent waiver, pharmaceutical companies cannot be forced to share the know-how required to manufacture these vaccines. This is critical because tacit knowledge plays a central role in complex manufacturing, especially for new technologies such as the mRNA. Additionally, since mRNA has not previously been used in vaccine production, workers with the skills to implement this technology are difficult to find. Even those from the traditional biopharmaceutical industry will need to undergo rigorous training to produce mRNA vaccines. Lack of knowledge, both tacit and codified, and production capacity may be the most significant constraints undermining the production expansion of vaccines that the world urgently needs.

How can we expand vaccine production capacity at a global scale rapidly? Castillo et al., (2021, p. 1107) "urge[d] governments and international organizations to contract with vaccine producers to further expand capacity". Based on the experience of six biopharmaceutical firms, Price, Rai, and Minssen (2020) found that rapid information exchange will not only be critical for the current crisis but could also create the foundation for fewer siloes and improved manufacturing standardization in the future. However, the contracts between these pharmaceutical firms are not public and almost all of the key information is redacted as confidential. Given the global spread of the pandemic and the speed of viral transmission, we need to develop production capacity across the globe to ensure that production capacity matches global demand and that the supply is reliable.

In addition to temporary IP protection waivers, there are also other proposed models, such as the use of public procurement as a policy tool, the introduction of a COVID-19 Vaccine Investment and Trade Agreement (CVITA) (Bown, 2021), or a reformed compulsory licensing arrangement (Athreye, 2021a, b; Meyer, 2021). Unfortunately, 
none of these by themselves are likely to resolve the problem.

Public procurement has been a useful method to encourage innovation. However, it is only effective in situations where there are strong innovation and production capabilities, and where public procurement can provide strong market demand to support the growth of the new product producers. This is not the case for COVID-19 vaccine where there is a clear market demand and government interest in purchasing vaccines.

Bown (2021) argues in favour of setting up a new and enforceable COVID-19 Vaccine Investment and Trade Agreement (CVITA). Such a CVITA can draw some lessons from the US subsidization and coordination of its domestic vaccine manufacturing supply chain under Operation Warp Speed (OWS), which succeeded in the US in coordinating clinical trials and scaling up manufacturing in advance of regulatory approval of potential vaccines. This approach was felt to be essential to making rapid progress to the vaccine production in the US, but was constrained by shortages in the supply chain and 'vaccine nationalism' that is prevalent in the US, Europe, India and Japan. Hence, a CVITA is proposed to create the incentives to ensure the timely and sizable scaling up of output and input investments to response to this pandemic and future pandemic threats. The investment component of the agreement is also designed to create a framework to subsidize the full vaccine manufacturing supply chain and especially to coordinate expansion of input production capacity. The agreement is also required to include an enforceable commitment on the part of participating countries not to place export restrictions on supplies of vaccines and related materials for other countries participating in the agreement.

The CVITA may help to unblock some of the obstacles encountered in existing global vaccine production cooperation between the big pharmaceutical companies and their partners, almost all in the developed countries, concerning in particular 'vaccine nationalism' and to subsidise the production of inputs and outputs. It may be suitable for some developed countries with strong medical innovation and pharmaceutical manufacturing capabilities, but the key question has now moved from those occurring in the early stage of vaccine development and production to global scale up. Additionally, developing countries are only marginally considered in this arrangement, although there is a sentence mentioning that participation of the poorest countries should be heavily subsidised. The poorest countries will very rarely have the technological capacity to join the current richcountry club. Moreover, the loose 'partnership' will not offer a strong push to help the developing countries to develop the production and gradually to acquire the technological capabilities in vaccine production that are needed in the long run.

Another alternative proposed to boost global vaccine production is reform of compulsory licensing under TRIPS (e.g. Athreye, 2021a, b; Meyer, 2021). It is argued that public funding to national universities and laboratories based on decades of research and scholarship is the unsung hero of the COVID-19 vaccine effort (Athreye, 2021a). This gives the justification and bargaining power to governments to force big pharmaceutical companies to follow this arrangement and to share their know-how. Admittedly, compulsory licensing of patents is a good short-run solution. It obliges the firm to share know-how in return for the license payment. However, current rules governing compulsory IP licensing are very restrictive. They only favour countries that already have productive capacity. Moreover, most of the tacit technological and managerial knowhow in supply chain management cannot be codified and transferred through compulsory licensing. Finally, successful technology transfer and local production capacity building based on compulsory licensing requires strong technological capabilities in the host country to understand the licensed technologies and to be able to convert them into locally useful production technology to build up production capacity. All of these difficulties pose significant challenges for most developing countries, especially in Africa and in low-income countries.

Admittedly, the conditions for successful compulsory licensing are similar to those that are likely to result in successful joint ventures - domestic absorptive capacity, willingness to transfer technology, and the political will of the government. In compulsory licensing, reducing prices is an objective in itself, whereas in joint ventures technology transfer takes centre stage. Where there is successful learning and where the IP is counted as part of the investment into the IJV, there will be a cheapening of the product in the long term. The reasons why joint ventures are preferred to compulsory licensing are that: (1) the IJV also brings in capital investment by the big pharmaceutical companies; (2) the IJV brings in technological and managerial knowhow that is much needed in the production of 
vaccine; (3) the IJV will be included in the MNE's network and will thus gain access to knowledge of the supply chain and its management; (4) a compulsory licence needs to be valid over the operating lifetime of the plant instead of "until the end of the pandemic", which may not be acceptable for IP owners; and (5) the enforcement of compulsion is rarely used - the requirements are too complex, especially for countries without local manufacturing capacity (Meyer, 2021).

\section{THE SOLUTION}

\section{International joint venture and technology transfer: Received wisdom}

In light of these constraints, we need a more feasible, effective, and sustainable way to support the development of COVID-19 manufacturing capabilities across the world. In particular, vaccine manufacturing is a multi-stage process that often requires extensive collaboration (Bown, 2021). Owners of the technology should be part of the collaboration partnership (Meyer, 2021) given the needs of transfer of tacit technological and managerial knowhow in addition to the patented technologies.

Licencing, imports, and foreign direct investment (FDI) are three of the most widely used methods for international technology transfer (Coe \& Helpman, 1995; Fagerberg, 1994; Freeman \& Soete, 1997; Fu \& Ghauri, 2021; Fu, Pietrobelli, \& Soete, 2011). Among them, FDI as a bundle of financial capital and technological and managerial knowledge is an effective vehicle that facilitates international knowledge diffusion and promotes industrialisation in developing host countries (Buckley et al., 2006; Dunning, 1994; Fu \& Hou, 2021; Fu et al., 2021a; Ghauri, Fu, \& Väätänen, 2017; Lall, 1996). The developing countries, especially the Newly Industrialised Economies and the Asian Tigers in East and South East Asia, and in the emerging economies such as China, have benefited from foreign technology transfer (Fu et al., 2011; Hou \& Mohnen, 2013; Hu, Jefferson, \& Qian, 2005; Javorcik, 2004; Lall, 1996, 2001; Liu \& Buck, 2007; Pietrobelli \& Rabellotti, 2007). MNEs' headquarters have internal incentives to encourage cross-board knowledge flows and to share technology subsidiaries from different locations (Brandt \& Rawski, 2019; Buckley and Ghauri, 2004; Buckley et al., 2006; Eapen, 2012; Markusen, 2002). Yet, crossborder technology transfers and diffusion are neither cost-free nor unconditional. They rely on well-directed technological efforts (Lall \& Pietrobelli, 2005) and on absorptive capacity in the host (Cohen \& Levinthal, 1989; Fu, 2008; Meyer, 2004).

Admittedly, despite the possible benefits of knowledge transfer and spill-overs initiated by FDI, a negative impact may also be revealed if the local industry is incapable of competing with MNEs or there is a lack of absorptive capacity (Aitken \& Harrison, 1999; Fu \& Gong, 2011; Xia \& Liu, 2017). Moreover, there has not been a universal Southern experience. Although some industries in China have been successful at technology transfer from joint ventures, Chinese firms in the high-technology sector have not been able to develop indigenous technological capabilities through FDI (Fu, 2015; Nolan, 2002). In the case of Africa, inter-firm technology transfer is limited due to limited linkages, weak local absorptive capacity, and cultural differences. In the case of Chinese MNEs, the language barrier is also an important inhibitor (Fu, Essegbey, \& Frempong, 2017). However, within MNE subsidiaries or joint ventures, technology transfers from foreign technologically more advanced partners succeed if the local partners have basic capabilities in the industry (Carrillo, 1996; Oguji et al., 2021). Effective communication, the development of business and social networks through informal and personal relationships, training, and teamwork helped to facilitate knowledge transfers at the individual level within joint ventures and subsidiaries (Carrillo, 1996; Fu et al., 2017; Kivrak et al., 2014). This also took place in joint ventures between Chinese and African partners (Ado et al., 2017; Fu et al., 2017).

Given the political risks, and institutional and market information constraints that are often faced by foreign companies in many developing countries, partnering with local firms to form joint ventures in host countries is one of the commonly used entry modes of foreign direct investment (FDI). The benefits of having a local partner have been widely recognized in previous studies, including gaining access to local markets and sharing business resources (Bontempi \& Prodi, 2009; Gattai \& Natale, 2013; Guillén, 2003; Kuo, Kao, \& Chang, 2012; Moskalev \& Swensen, 2007). Alliances also potentially create value by combining complementary resources and facilitating joint learning ( $\mathrm{Fu}$ et al., 2021b; Soh \& Subramanian, 2014).

This kind of joint venture model has several advantages in comparison to a wholly foreignowned subsidiary (WFOS): 
Firstly, in comparison to a WFOS, joint ventures with local firms supported by local government can tap into local knowledge in areas like resources, markets and supply chains, which are important for the success and sustainability of the joint venture (Bontempi \& Prodi, 2009). The existing labour force and production facilities can be integrated into the new joint venture for a quick start.

Secondly, forming joint ventures can significantly reduce the political risk for foreign firms in a host country, especially in countries with underdeveloped institutions (Cristina \& Marta, 2010)

Thirdly, a public-private partnership will be able to bring resources and skills from a wide range of stakeholders. It will also integrate the private sector's advantage in flexibility, innovation, and ability to deliver and the public sector's strengths in mobilising resources and wide outreach at a particularly difficult time (UN DESA, 2021).

Finally, joint ventures are important vehicles for international technology transfer. By working together with local staff within a joint venture, technological and managerial knowledge will be transferred to the local employees and partners through training and various work interactions. Although the inter-organisational technology transfer in Africa is constrained due to limited linkages (Fu, Buckley, \& Fu, 2020; Oguji et al., 2021) knowledge transfer and spill-overs within the MNEs at the employee level remain significant for both Western and Chinese MNEs. This is the case even in multinational enterprises (MNEs) in Africa and is likely to lead to more rapid production growth than any other strategy (Fu, Essegbey, \& Promkon, 2019).

\section{The policy model for international joint ventures}

Therefore, based on the received wisdom in the literature on technology transfer and management studies (Lall, 1996), and considering the substantial tacit technical and managerial knowledge required for the production of this complex vaccine, we propose to incentivise and engage with pharmaceutical companies more intensively to encourage joint ventures. The aim should be to encourage MNEs to share not only their patents but also their tacit production knowledge with manufacturers across the world. In order to do that, we believe that joint ventures between leading pharmaceutical companies and local pharmaceutical companies based in the global South should be promoted. These joint ventures will form regional manufacturing hubs and can be financed by governments in the global North, the host countries, international organisations and pharmaceutical companies. The financial fallout of the COVID-19 pandemic has clearly demonstrated that investment in these novel vaccines is economically viable for all aforementioned actors. Moreover, this IJV solution not only promotes joint ventures for the production of the final product of the vaccine but also those joint ventures that produce various key components in the whole vaccine supply chain that are undersupplied or whose production are highly geographically concentrated.

Although changes to intellectual property rights are welcome, this approach will have a more significant impact on vaccine production in the near future. It will also offer long-term benefits to the global South by stimulating the life science industry and technological capability building. Moreover, this initiative may have wider implications in enhancing global public goods provision and global knowledge sharing, which are critical to addressing other global challenges such as climate change.

The joint venture and hubs solution that we are calling for is supported by others. Indeed, the Africa Union and the Africa Centres for Diseases Control and Prevention (Africa CDC) have recently proposed the establishment of five pharmaceutical manufacturing hubs to accelerate COVID-19 vaccine manufacturing on the continent. Countries such as South Africa and Senegal with vaccineproducing experience, as well as Rwanda, which is making plans to host Africa's first mRNA vaccine plant, have been identified as ideal locations for these regional hubs (Pilling, 2021; Wilson \& Butera, 2021).

The formation of joint ventures is made by two groups of firms: the pharmaceutical companies with headquarters in the global North and the local firms in the global South, who can both actively seek new partnerships. Governments in both global North and South can support new partnerships by providing information, the necessary infrastructure, training, and preferential policies, such as tax exemption, low-interest-rate loans, and linking local universities and research institutions with these joint ventures. In principle, this can be a bottom-up, market-based activity, instead of a top-down process. The final location of regional hubs in different continents could be approved and supported by a special taskforce coordinated by the World Health Organization (WHO), United Nations (UN) agencies for 
technology transfer and industrial development, and international organisations that could provide extra funding to the joint ventures.

\section{The actors and incentives}

Here we identify the five types of players that will be involved in this global vaccine technology transfer and production acceleration program as well as the main incentives for each of them.

(1) The pharmaceutical companies that have the patents and knowledge for the production of vaccine. These companies will have incentives to create joint ventures because they will benefit directly from expansion of production capacity, markets and profits. The public-private partnership will also bring in investment that should be cheaper than capital raised from the market, while reducing entry barriers and political risk. In the long run, pharmaceutical companies will not necessarily lose from sharing this information; in fact, they could even benefit from the maximisation of stakeholder value (Jensen, 2017); and the improvement in their public image and brand value.

(2) Local pharmaceutical companies in regional hubs. They will be keen to join such a partnership because this is a rare opportunity for technology transfer and capabilities upgrading, and even leapfrogging to emerging frontier technological areas.

(3) Governments in the global North. They will be interested in supporting our proposal because this is a global pandemic and economic recovery will only be possible when the pandemic is defeated globally, given the high mobility of people and the global organisation of supply chains. The US, France, Germany, China and many other country governments have already contributed to the global pandemic battle by supporting the Access to COVID-19 Tools (ACT) Accelerator, including the COVID-19 Vaccines Global Access (COVAX) facility set up by the World Health Organization (WHO) and partners.

(4) Governments in the global South, especially in the countries where the regional hubs are located. They will be supportive of this initiative given its importance to end the pandemic and the serious under-provision of vaccines in the global South. Our proposal also offers them a rare opportunity for technology transfer, industrial upgrading and structural change.
(5) International organisations such as WHO including COVAX, the United Nations, the World Bank, and the IMF. They will actively support the creation of joint ventures and regional hubs given their mission. This is also proved by the efforts made by these international organisations in the past year. Given the large demand for the vaccine and the current information on the cost of a dose, as discussed earlier, the financial return will be positive.

(6) An international coordination mechanism will be established based on existing programs and initiatives, especially COVAX and the Access to COVID-19 Tools Accelerator (ACT-A).

In the case of international technology transfer of environmental technologies, the encouraging progress made via IJV also depends on the presence of institutional support, for example the Clean Development Mechanism (CDM) under the Kyoto protocol. In the CDM, the UNFCCC allowed countries to accumulate carbon credits if there was successful technology transfer via the IJV. Therefore, to accelerate technology transfer of vaccine technologies, an international coordination mechanism based on COVAX and ACT-A shall be established to ensure the successful technology transfer via the IJV. This coordination mechanism will be supported by the existing International Health Regulations Treaty (IHR), Medicines Patent Pool (MPP) set up by UNITAID, which is meant to encourage technology transfer and has produced licensing agreements so that generics manufacturers can make cheaper versions of, mainly HIV treatments.

COVAX (which is co-led by CEPI, GAVI and WHO) will continue to play an important role in leading the expansion of global vaccine production, by providing seed funding, helping with jointventure matchmaking, setting product quality standards, and ensuring quality monitoring. Therefore, this proposed IJV solution does not replace or weaken the role of COVAX, but instead provides alternative solutions that effectively unblock the major bottlenecks that constrained COVAX, namely the lack of funding, because the MNEs will bring in funding, and strengthen tacit knowledge transfer, which is critical for the production of vaccines and in organising the supply chain. COVAX will also oversee the global distribution of the production bases, including both the final vaccine production and the key components production, making sure urgent supplies can be 
delivered to every country that is in need of vaccine. The risks of production and in the supply chain are diversified by having multiple production bases for each stage of the vaccine production chain.

\section{THE BENEFITS AND RISKS}

Our proposal will ultimately deliver the following benefits. First, this policy approach takes advantage of the key strengths of MNEs: their flexibility, focus on innovation and ability to deliver. Research has shown that when MNEs partner with local firms, transfers of these resources and skills can improve their production capabilities and consequently increase output, resulting in win-win situations. Moreover, they can help to orchestrate the complex global supply chain, which is needed for vaccine production, by increasing their presence globally (Buckley, 2009).

In the long term, our proposal would also stimulate the development of scientific and technological capabilities in the global South that are heavily dependent on the import of vaccines. By setting up joint ventures with MNEs, companies in these countries can learn how to use new pharmaceutical technologies, which has immense economic, scientific and health benefits. This knowledge transfer can support the development of pharmaceutical industries across the world, leading to new job opportunities and upgraded productive capabilities. Moreover, this approach may incentivise researchers and scientists across the world to keep on innovating and creating solutions to address other threatening diseases. Scientists have already been working to apply the mRNA technology to other infectious diseases such as Ebola and even cancer (Komaroff, 2020). Our proposed strategy may therefore support global health management more broadly.

The success of these joint ventures will be dependent on the availability of essential raw materials needed for production. Countries in the global North need to realise that this global emergency requires the suspension of any controls and IP that limits the exports of all essential material and components required for vaccines production. We should also encourage MNEs to create joint ventures for the production of some key materials and components in order to release the current bottlenecks at various points in the vaccine supply chain.

For the MNEs, forming joint ventures is not only a way to gain returns from investment in $R \& D$ in comparison to compulsory licensing but also a way to expand their production capacity and to expand their marketing to (normally) highly regulated foreign markets in comparison to direct export, gaining political support from host-country governments and international organisations in comparison to wholly foreign-owned subsidiaries, and enabling them to maximise their stakeholder value, which is important for their long-term sustainable growth.

Admittedly, joint ventures as a type of alliance are not without risk. A successful joint venture requires shared goals, trust in each partner, effective communication, and a design to distribute the gains from the partnership fairly. These factors need particular attention at the match-making and joint venture formation stage. The participation of international organisations and the coordination of COVAX facility will help to reduce the opportunistic behaviour on either side of the partnership.

The risk that foreign partners learn from the principals and replace their position in the market is low because in this highly knowledge-intensive industry, competitive advantage comes from continuous investment in costly R\&D and innovation. As long as the leading pharmaceutical companies make profits and keep on innovating, they will stay on the scientific frontier, and these joint ventures will be a cash cow producing profits from mature products.

Another possible risk is the tension between value creation and value appropriation among IJV partners (Inkpen \& Beamish, 1997). However, partners also compete to appropriate knowledge and value for their private benefits (Hamel, Doz, \& Prahalad, 1989). Recent papers on international joint ventures (e.g. Sun, Deng, \& Wright, 2021) suggest international joint ventures in emerging markets that involve making deals with political institutions in order to get the venture going, may also create risks of opportunism once the technology has been transferred. There is political pressure for the MNE partnering with state-owned firms to innovate. State partners are powerful in boosting IJV innovation investment but this can limit the shaping of IJV innovation outcomes. However, based on findings from their research, Sun et al. (2021) caution against an overly protective approach to managing transactional hazards. They argue that "it may be reasonable to increase hazardous investments, which act as a price of admission to a host market and a steppingstone to leverage a continuous flow of essential resources from host-country political institutions". They also "prompt managers to develop a 
more sophisticated evaluation of the prowess of their political partners. In the case of knowledgebased cooperative activities, some powerful partners may not be as dangerous as the case in physicalcapital-intensive ventures".

\section{CONCLUSION}

This is the moment to work together if we want to overcome the current crisis. We need an "all hands on deck" approach. Accelerating the production of the COVID-19 vaccine through joint ventures and other collaborative mechanisms and waiving patents to these partnerships should not only allow us to end this pandemic but also presents a rare window of opportunity to support technological capabilities upgrading and sustainable economic development across the global South. This initiative may even pioneer a new way to enhance global public goods provision and global knowledge sharing, which is vital to tackling other global challenges and achieving the sustainable development goals. We should not waste this unique opportunity.

International collaboration in vaccine production should be open to all combinations of actors, including North-South and South-South. SouthSouth direct investments have been found to be effective for host developing countries when their advantages match the needs of the host countries and unblock a bottleneck that constrains the growth of a host country (Fu, Buckley, \& Fu, 2020). The experience of successful technology transfer in lowcarbon energy technologies also suggests that IJV are effective channels for international technology transfer related to public goods to the developing and emerging countries (e.g. Fu \& Zhang, 2011; Kirchherr \& Urban, 2018; Lema, Fu, \& Rabellotti, 2020), given the presence of suitable government policies and adequate capacities in the recipient country. Kirchherr and Urban (2018) find that a common key success factor is joint ventures in their Meta analysis. These IJVs set up excellent examples for the international technology transfer through South-South and North-South technology transfer and cooperation for other public goods for the global community, like global health.

\section{REFERENCES}

Ado, A., Su, Z., \& Wanjiru, R. 2017. Learning and knowledge transfer in Africa-China JVs: Interplay between informalities, culture, and social capital. Journal of International Management, 23(2): 166-179.
In the case of vaccine production, there are different technology pathways and different levels of efficacy regarding the elimination of a specific virus. Although the mRNA approach appears to have a higher level of efficacy in the case of the COVID-19 virus, the more mature Vero or Adenoviruses technologies of vaccine may be more useful for some unknown disease or virus that may occur in the future. Therefore, supported by a strong scientific and economic rationale, pharmaceutical companies and governments in the South should include the IJV solution into their consideration of future strategies for international development and international business.

Of course, successful international transfer of vaccine technologies requires the presence of some important pre-conditions, especially the presence of absorptive capacity in the host countries, which requires a threshold level of skills, technological capabilities, and innovation efforts. These are critical factors to consider in the selection of regional hubs and are also important areas for host-country governments to work on. Nevertheless, compared to environmental technologies, vaccine technologies are more focused in terms of scope, variety and scale. Therefore, given the progress made in green technology transfer through IJV, we shall be confident that with appropriate and effective arrangements, the joint venture approach will have a significant impact on vaccine production.

\section{ACKNOWLEDGEMENTS}

We are grateful to Heide Hackmann, E. William Colglazier, Luc Soete, Suma Athreye, Koen Jonkers, Alessandro Fazio, Mattias Dinnetz and Klaus Meyer for their helpful comments, to Kenneth Shadlen for his inputs in previous conversations, to Joseph Stiglitz, Jeffery Sachs, Luc Soete, and Carlos Lopes for inspiring discussions made at an UNIDO meeting, which enlightened us about the wide relevance of our proposed approach, to conference participants at the 2021 EPIP Annual Conference for helpful comments, and to Nwamaka Ogbonna for excellent research assistance.

Aitken, B. J., \& Harrison, A. E. 1999. Do domestic firms benefit from direct foreign investment? Evidence from Venezuela. American Economic Review, 89(3): 605-618. 
Athreye, S. 2021a. Vaccine platforms and limited global production capacity: What is to be done? Retrieved from https://ipkitten.blogspot.com/2021/05/vaccine-platformsand-limited-global.html on September 8, 2021.

Athreye, S. 2021b. Knowledge transfer from Public Science: The unsung hero of the COVID-19 vaccine success. Retrieved from http://www7.bbk.ac.uk/cimr/2021/03/03/knowledgetransfer-from-public-science-the-unsung-hero-of-the-covid19-vaccine-success/ on September 8, 2021.

Bontempi, M., \& Prodi, G. 2009. Entry strategies into China: The choice between Joint Ventures and Wholly Foreign-Owned Enterprises: An application to the Italian manufacturing sector. International Review of Economics \& Finance, 18(1): 11-19.

Bown, C. P. 2021. Here's how to get billions of COVID-19 vaccine doses to the world. Peterson Institute for International Economics. Retrieved from https://www.piie.com/blogs/ trade-and-investment-policy-watch/heres-how-get-billionscovid-19-vaccine-doses-world.

Brandt, L., \& Rawski, T. 2019. Policy, regulation and innovation in China's electricity and telecom industries. Cambridge: Cambridge University Press.

Buckley, P. J. 2009. The impact of the global factory on economic development. Journal of World Business, 44(2): 131-143.

Buckley, P. J., \& Ghauri, P. N. 2004. Globalisation, economic geography and the strategy of multinational enterprises. Journal of International Business Studies, 35(2): 81-98.

Buckley, P. I., Clegg, J., \& Tan, H. 2006. The art of knowledge transfer: Secondary and reverse transfer in China's telecommunications manufacturing industry. Basingstoke: Palgrave Macmillan.

Carrillo, P. 1996. Technology transfer on joint venture projects in developing countries. Construction Management and Economics, 14(1): 45-54.

Castillo, J. C., Ahuja, A., Athey, S., Baker, A., Budish, E., Chipty, T., et al. 2021. Market design to accelerate COVID-19 vaccine supply. Science, 371(6534): 1107-1109.

Cheng, M., \& Hinnant, L. 2021. Countries urge drug companies to share vaccine know-how. Retrieved from https://apnews. com/article/drug-companies-called-share-vaccine-info22d92afbc3ea9ed519be007f8887bcf6.

Coe, D. T., \& Helpman, E. 1995. International R\&D spillovers. European Economic Review, 39(5): 859-887.

Cohen, W., \& Levinthal, D. 1989. Innovation and learning: two faces of R\&D. Economic Journal, 99: 569-596.

Cristina, L. D., \& Marta, M. V. 2010. External uncertainty and entry mode choice: Cultural distance, political risk and language diversity. International Business Review, 19(6): 575-588.

Dunning, J. H. 1994. Multinational enterprises and the globalization of innovatory capacity. Research Policy, 23: 67-88.

Dyer, O. 2021. Covid-19: Countries are learning what others paid for vaccines. Retrieved from https://www.bmj.com/ content/372/bmj.n281. Accessed on September 8, 2021.

Eapen, A. 2012. Social structure and technology spillovers from foreign to domestic firms. Journal of International Business Studies, 43: 244-263.

Fagerberg, J. 1994. Technology and international differences in growth rates. Journal of Economic Literature, 32(3): 1147-1175.

Freeman, C., \& Soete, L. 1997. The economics of industrial innovation ( 3 rd ed.). London: Pinter.

$\mathrm{Fu}, \mathrm{X}$. 2008. Foreign direct investment, absorptive capacity and regional innovation capabilities: evidence from China. Oxford Development Studies, 36(1): 89-110.

Fu, X. 2015. China's path to innovation. Cambridge: Cambridge University Press.

Fu, X., Buckley, P., \& Fu, X. M. 2020. The growth impact of Chinese direct investment on host developing countries. International Business Review, 29(2): 101658.

Fu, X., Emes, D., \& Hou, J. 2021a. Multinational enterprises and structural change in developing countries: A survey of literature. International Business Review, 30(2): 101801.

Fu, X., Essegbey, G., \& Frempong, G. 2017. MNEs and capabilities building in Ghana. Bingley: Emerald Publishing Limited.
Fu, X., Essegbey, G., \& Promkon, G. 2019. MNEs, knowledge transfer and capabilities upgrading. Cheltenham: Edward Elgar.

$\mathrm{Fu}, \mathrm{X} ., \&$ Ghauri, P. 2021. Trade in intangibles and the global trade imbalance. The World Economy, 44(5): 1448-1469.

$\mathrm{Fu}, \mathrm{X}$. , \& Gong, Y. 2011. Indigenous and foreign innovation efforts and drivers of technological upgrading: evidence from China. World Development, 39(7): 1213-1225.

$\mathrm{Fu}, \mathrm{X} .$, \& Hou, J. 2021. Foreign technology transfers in China. In X. Fu, B. McKern, \& J. Chen (Eds.), Oxford handbook of China innovation. Oxford: Oxford University Press.

Fu, X., Li, Y., Li, J., \& Chesbrough, H. 2021b. When do latecomer firms undertake international open innovation: Evidence from China. Global Strategy Journal. https://doi. org/10.1002/gsj.1401.

Fu, X., Pietrobelli, C., \& Soete, L. 2011. The role of foreign technology and indigenous innovation in the emerging economies: Technological change and catching-up. World Development, 39(7): 1204-1212.

Fu, X., \& Zhang, J. 2011. Technology transfer, indigenous innovation and leapfrogging in green technology: Solar-PV panel industries in India and China. Journal of Chinese Economics and Business Studies, 9(4): 329-347.

Gattai, V., \& Natale, P. 2013. What makes a joint venture: Micro-evidence from Sino-Italian contracts. Review of Financial Economics, 22(4): 194-205.

Ghauri, P. N., Fu, X., \& Väätänen, J. 2017. Multinational enterprises, sustainable development and poverty alleviation: past, present, and future. Bingley: Emerald Publishing Limited. Gonsalves, G. 2021. The COVID-19 patent waiver: a crucial step towards a people's vaccine. The BMJ Opinion. https://www. bmj.com/content/373/bmj.n1249. Accessed 8 July 2021.

Guillen, M. 2003. Experience, imitation, and the sequence of foreign entry: Wholly owned and joint-venture manufacturing by South Korean firms and business groups in China, 19871995. Journal of International Business Studies, 34(2): 185-198.

Hamel, G., Doz, Y., \& Prahalad, C. K. 1989. Collaborate with your competitors and win. Harvard Business Review, 67(1): 133-139.

Hotez, P. I., Bottazzi, M. E., \& Yadav, P. 2021. Producing a vaccine requires more than a patent intellectual property is just one piece of an elaborate process. Foreign Affairs, May 10. https://www.foreignaffairs.com/print/node/1127488. Accessed 8 July 2021.

Hou, J., \& Mohnen, P. 2013. Complementarity between inhouse $R \& D$ and technology purchasing: Evidence from Chinese manufacturing firms. Oxford Development Studies, 41(3): 343-371.

Hu, A., Jefferson, G., \& Qian, J. 2005. R\&D and technology transfer: Firm-level evidence from Chinese industry. Review of Economics and Statistics, 87(4): 780-786.

Inkpen, A. C., \& Beamish, P. W. 1997. Knowledge, bargaining power, and the instability of international joint ventures. Academy of Management Review, 22(1): 177-202.

Javorcik, B. 2004. Does foreign direct investment increase the productivity of domestic firms? In search of spillovers through backward linkages. American Economic Review, 94(3): 605627.

Jensen, M. M. 2017. Value maximisation, stakeholder theory and the corporate objective function. In J. Andriof, S. Waddock, B. Husted, \& S. S. Rahman (Eds.), Unfolding stakeholder thinking: Theory, responsibility and engagement. London: Routledge. https://doi.org/10.4324/9781351281881.

Kirchherr, J., \& Urban, F. 2018. Technology transfer and cooperation for low carbon energy technology: Analysing 30 years of scholarship and proposing a research agenda. Energy Policy, 119: 600-609. https://doi.org/10.1016/j.enpol.2018. 05.001.

Kivrak, S., Arslan, G., Tuncan, M., \& Birgonul, M. T. 2014. Impact of national culture on knowledge sharing in international construction projects. Canadian Journal of Civil Engineering, 41(7): 642-649. 
Komaroff, A. 2020. Why are $m R N A$ vaccines so exciting? Boston: Harvard Health Publishing. https://www.health.harvard.edu/ blog/why-are-mrna-vaccines-so-exciting-2020121021599. Accessed 1 June 2021

Kuo, A., Kao, M., \& Chang, Y. 2012. The influence of international experience on entry mode choice: Difference between family and non-family firms. European Management Journal, 30(3): 248-263.

Lall, S. 1996. Paradigms of development: The East Asian debate on industrial policy. In: Learning from the Asian Tigers. London: Palgrave Macmillan.

Lall, S. 2001. The economics of technology transfer. Cheltenham: Edward Elgar Publishing.

Lall, S., \& Pietrobelli, C. 2005. National technology systems in sub-Saharan Africa. International Journal of Technology and Globalisation, 1(3-4): 311-342.

Lema, R., Fu, X., \& Rabellotti, R. 2020. Green windows of opportunity: latecomer development in the age of transformation toward sustainability. Industry and Corporate Change, 29(5): 1193-1209.

Liu, X., \& Buck, T. 2007. Innovation performance and channels for international technology spillovers: Evidence from Chinese high-tech industries. Research Policy, 36: 355-366.

Markusen, J. R. 2002. Multinational firms and the theory of international trade. Cambridge: MIT Press.

Meyer, K. 2021. A Covid-19 vaccine plant in Africa-What would it take to build one? https://theconversation.com/acovid-19-vaccine-plant-in-africa-this-is-what-it-would-take-tobuild-one-162778. Accessed 1 September 2021.

Meyer, K. E. 2004. Perspectives on multinational enterprises in emerging economies. Journal of International Business Studies, 35(4): 259-276.

Middleton, J., Wong, B., Green, M., Reid, J., \& Martin-Moreno, J. M. 2021. We need an equitable and coordinated global approach to covid-19 vaccination. https://blogs.bmj.com/ bmj/2021/01/28/we-need-an-equitable-and-coordinatedglobal-approach-to-covid-19-vaccination/.

Moskalev, S. A., \& Swensen, R. B. 2007. Joint ventures around the globe from 1990-2000: Forms, types, industries, countries and ownership patterns. Review of Financial Economics, 16(1): 29-67.

Nolan, P. 2002. China and the global business revolution. Cambridge Journal of Economics, 26(1): 119-137.

Office of the United States Trade Representative. 2021. Statement from Ambassador Katherine Tai on the Covid-19 Trips Waiver. https://ustr.gov/about-us/policy-offices/press-office/ press-releases/2021/may/statement-ambassador-katherinetai-covid-19-trips-waiver. Accessed 1 July 2021.

Oguji, N., William, Y., Degbey, W. Y., \& Owusu, R. A. 2021. International joint ventures research on Africa: A systematic literature review, propositions, and contextualization. Thunderbird International Business Review., 63(1): 11-26.

Our World in Data. 2021. Coronavirus (COVID-19) vaccinations: Statistics and Research. Retrieved from https://ourworldindata. org/covid-vaccinations?country=GBR on August 19, 2021.

Pietrobelli, C., \& Rabellotti, R. 2007. Business development service centres in Italy: Close to firms, far from innovation. World Review of Science, Technology and Sustainable Development, 4(1): 38-55.

Pilling, D. 2021. Africa celebrates suspension of Covid vaccine patients. Financial Times. https://www.ft.com/content/ ad64d561-f6e4-483b-994b-0a91e8dbaf8b. Accessed 1 September 2021.

Price, W. N., Rai, A. K., \& Minssen, T. 2020. Knowledge transfer for large-scale vaccine manufacturing. Science, 369(6506): 912914.
Shadlen, K. 2020. To speed new COVID drugs and vaccines, look to patenting. Issues in Science and Technology. Retrieved from https://issues.org/covid-vaccines-developmentdistribution-patenting-shadlen/ on August 11, 2020.

Soh, P. H., \& Subramanian, A. M. 2014. When do firms benefit from university-industry R\&D collaborations? The implications of firm R\&D focus on scientific research and technological recombination. Journal of Business Venturing, 29(6): 807-821.

Sun, P., Deng, Z., \& Wright, M. 2021. Partnering with Leviathan: The politics of innovation in foreign-host-state joint ventures. Journal of International Business Studies, 52: 595-620.

UN DESA. 2021. Partnership in response to the pandemic: Building back better. https://sdgs.un.org/publications/ partnerships-response-covid-19-building-back-bettertogether-33018. Accessed 1 September 2021.

WHO. 2021. What is Africa's vaccine capacity? https://www. afro.who.int/news/what-africas-vaccine-production-capacity. Accessed 1 September 2021.

Wilson, L., \& Butera, S. 2021. Rwanda President seek to bring first mRNA vaccine plant to Africa. Bloomberg. https://www. bloombergquint.com/business/rwanda-s-paul-kagame-saysworking-on-africa-mrna-vaccine-plant. Accessed 1 September 2021.

Xia, T., \& Liu, X. 2017. Foreign competition, domestic competition and innovation in Chinese private high-tech new ventures. Journal of International Business Studies, 48(6): 716-739.

\section{ABOUT THE AUTHORS}

Xiaolan Fu is Founding Director of the Technology and Management Centre for Development (TMCD), Professor of Technology and International Development, University of Oxford, and a Fellow of the Academy of Social Sciences. She was appointed by the Secretary-General of the UN to the Governing Council of the UN's Technology Bank for Least Developed Countries.

Peter J. Buckley is Professor of International Business, Founder Director of CIBUL at the University of Leeds. He is a Fellow of the Academy of International Business, the Royal Society of Arts, and the British Academy.

Diego Sanchez-Ancochea is Professor of the Political Economy of Development, Head of Department of International Development, University of Oxford.

Ines Hassan is a Senior Consultant at the International Science Council, and a Senior Policy Researcher at the Global Health Governance Programme at the Usher Institute, University of Edinburgh.

Publisher's Note Springer Nature remains neutral with regard to jurisdictional claims in published maps and institutional affiliations.

Accepted by Sarianna Lundan, Editor-in-Chief, 16 October 2021. This article has been with the authors for two revisions. 